\title{
Treatment of congenital radial head dislocation with a computer-assisted hexapod external fixator: A case report
}

\section{Konjenital radius başı çıkığının bilgisayar destekli heksapod eksternal fiksatör ile tedavisi: Olgu sunumu}

Özgür Karakoyun, Mehmet Fatih Erol, Mesut Karıksız

\begin{abstract}
Congenital dislocation of the radial head (CDRH), a congenital anomaly of the elbow, can cause symptoms such as joint stiffness, snapping, locking, or pain, however the diagnosis is sometimes made incidentally from $\mathrm{x}$-rays. The treatment goal is to ameliorate the symptoms and obtain a joint with a full range of motion. This paper presents a case of unilateral CDRH that was asymptomatic until adolescence, when locking and snapping developed. Several treatment options are described in the literature. Although the conventional and computer-assisted external fixator systems are used in several clinical pictures such as extremity deformities, joint contractures and fixation of acute fractures etc a computer-assisted external fixator system has not been used for CDRH. We successfully performed ulnar dorsal translation and a lengthening osteotomy with a computer-assisted external fixator to reduce the radial head indirectly and had satisfactory functional and clinical results. J Clin Exp Invest 2015; 6 (3): 301-305
\end{abstract}

Key words: Radial head, congenital dislocation, hexapod external fixator

\section{INTRODUCTION}

Congenital dislocation of the radial head (CDRH), a congenital anomaly of the elbow, can cause symptoms such as joint stiffness, snapping, locking, or pain, although the diagnosis is sometimes made incidentally from x-rays. The treatment goal is to ameliorate the symptoms and obtain a joint with a full range of motion. The treatment options include arthroscopic release, open annular ligamentoplasty, open reduction, ulnar angulation osteotomy, and indirect reduction of the radial head with external fixators. Although the conventional and computerassisted external fixator systems are used in sev-

\section{ÖZET}

Konjenital radius başı çıkığı (KRBÇ) dirsekte eklem sertliği, atlama, kilitlenme veya ağrıya neden olabilen doğumsal bir anomalidir. Bunun yanında tanı insidental olarak çekilen direkt grafilerle de konulabilmektedir. Tedavide amaç semptomları iyileştirmek ve hareket açıklığı tam olan bir dirsek eklemi elde etmektir. Literatürde çeşitli tedavi yöntemleri bildirilmektedir. Konvansiyonel veya bilgisayar destekli eksternal fiksatör sistemleri ekstremite deformiteleri, eklem kontraktürleri, akut kırıkların tespiti gibi klinik durumlarda kullanılmaktadır. Ancak bilgisayar destekli eksternal fiksatör ile tedavi edilmiş bir KRBÇ olgusuna rastlanmamaktadır. Bu yazımızda adelosan çağına kadar asemptomatik olan ve sonrasında dirsekte kilitlenme ve atlama şikayetleri ile kliniğimize başvuran ve proksimal ulna translasyon ve uzatma osteotomisi ve bilgisayar destekli eksternal fiksatör tatbiki ile başarılı bir şekilde tedavi ettiğimiz KRBÇ olgusunun fonksiyonel klinik ve radyolojik sonuçlarını sunuyoruz.

Anahtar kelimeler: Radius başı, konjenital çıkık, hegzapod eksternal fiksatör

eral clinical pictures such as extremity deformities, joint contractures and fixation of acute fractures etc a computer-assisted external fixator system has not been used for $\mathrm{CDRH}$ [1]. Some authors recommend simply following asymptomatic cases [2]. Since there are few reports on cases treated with each method, the optimal treatment approach remains controversial.

\section{CASE REPORT}

A 17-year-old male presented to our clinic with pain and locking in the right elbow without any history of trauma. He had been asymptomatic until adolescence. A physical examination showed pain on flex- 
ion of the right elbow, with flexion limited to $70^{\circ}$. The ranges of extension, pronation, and supination were full. Routine anteroposterior (AP) and lateral elbow $\mathrm{X}$-rays revealed anterior dislocation of the right radial head (Figure 1). There were no accompanying neurological disorders or any history of elbow trauma. We diagnosed congenital anterior dislocation of the radial head. We decided to reduce the radial head indirectly, with proximal ulnar translation and a lengthening osteotomy using a computer-assisted hexapod external fixator (CAHEF).

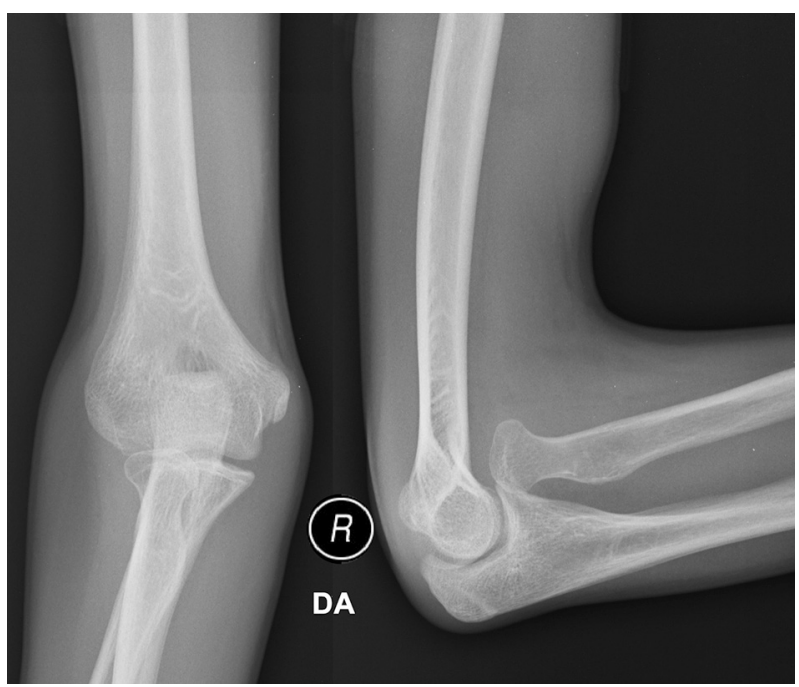

Figure 1. Anteroposterior (AP) and lateral x-rays of congenital dislocation of the radial head

\section{Preoperative planning}

As in all osteotomies, preoperative planning is the mandatory first treatment step. We planned the os- teotomy and gradual lengthening and translation using CoreIDRAW® Graphic Suite X6 (Corel, Ottawa, ON, Canada) (Figure 2). First, we imported the AP and lateral $\mathrm{x}$-rays of the right elbow into the software program. The radial head was reduced in the program and the dorsal translation and lengthening of the ulna after reduction were calculated. The CAHEF system used the data from this calculation as deformity parameters.

\section{Operation and aftercare}

Under anesthesia, while the patient was in the supine position, one 5/8 hexapod external ring and two Schanz screws were inserted into the ulna, proximally and distally. Six telescopic rods were attached to the rings. A proximal ulnar osteotomy was made using the drill osteotomy technique.

On the first postoperative day, active range of motion exercises were started in all directions without any restriction (Figure 3). After a 5-day latent period, the mounting parameters and previously calculated parameters were loaded into the CAHEF system software (Figure 4). First, the lengthening and then the translation options were selected to prevent the radial head from sticking to the capitellum during lengthening. At the end of the translation and lengthening procedures, the radial head had been reduced indirectly and the consolidation phase started. After 2 months of consolidation, the external fixator was removed in our outpatient clinic (Figure 5). The patient's symptoms had disappeared and the joint range of motion was full in all directions (Figure 6).
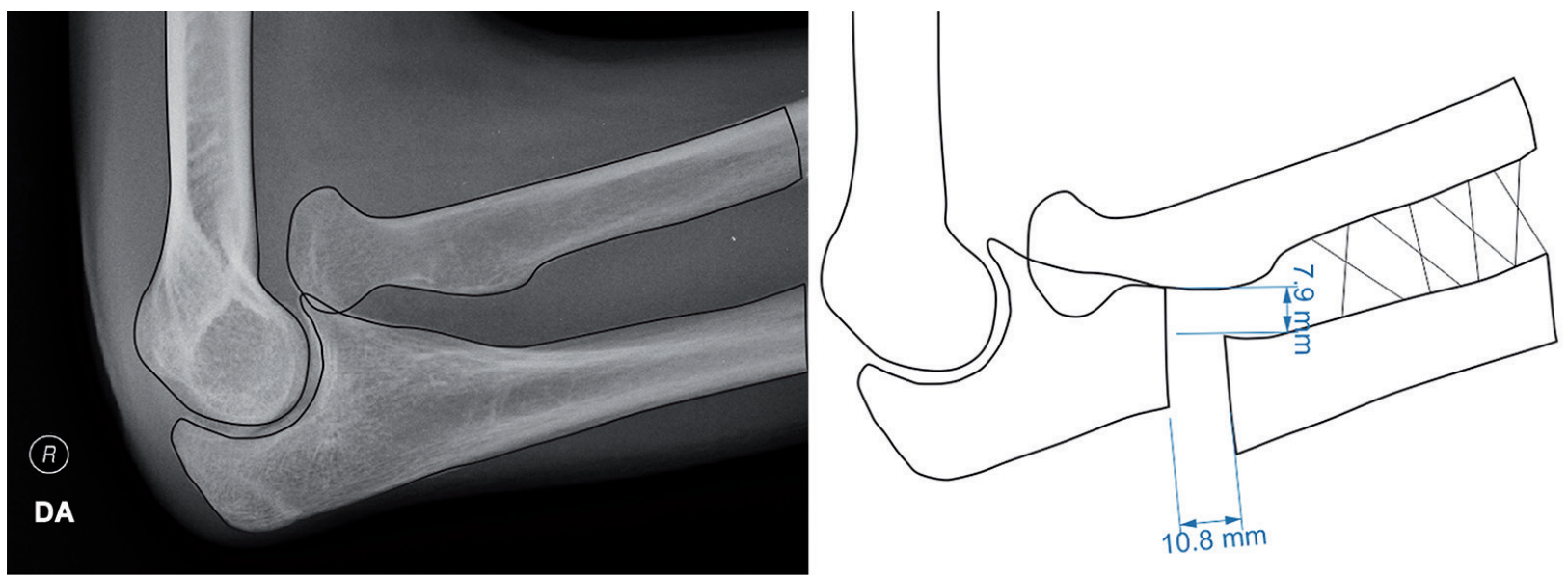

Figure 2. Preoperative planning using CoreIDRAW® Graphic Suite X6 


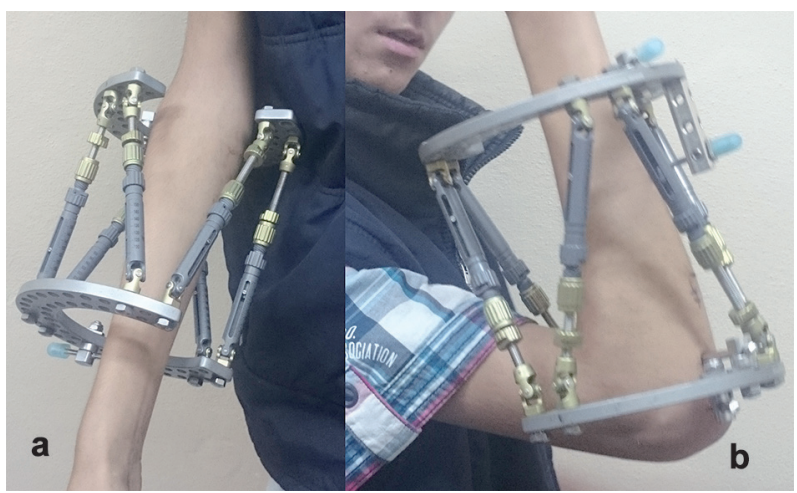

Figure 3. Postoperative active flexion and extension of the elbow

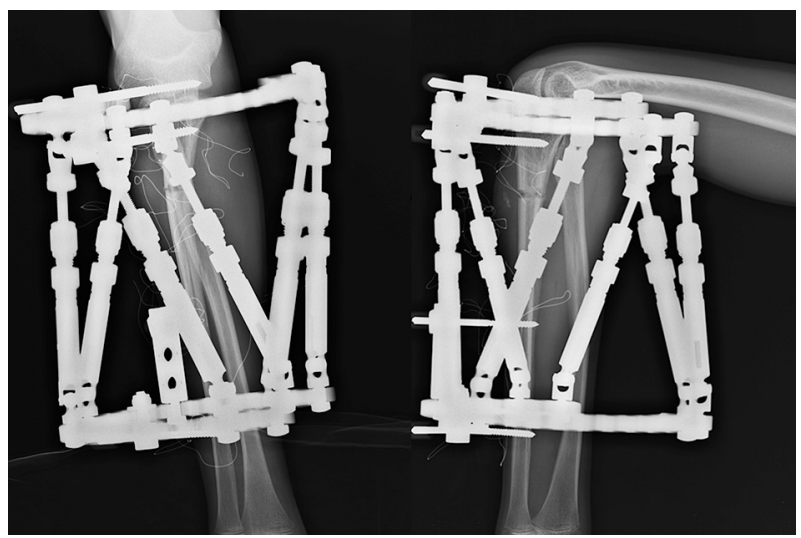

Figure 4. Postoperative AP and lateral x-rays, which were used to calculate the montage parameters

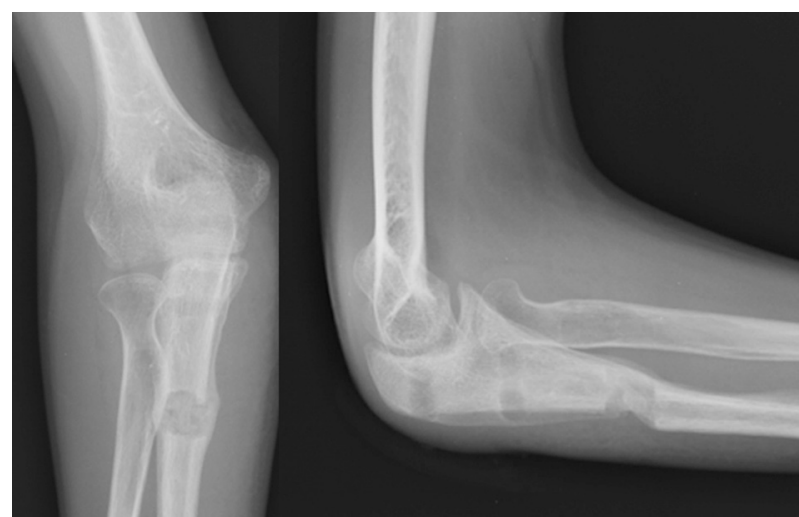

Figure 5. AP and lateral x-rays after removing the external fixator

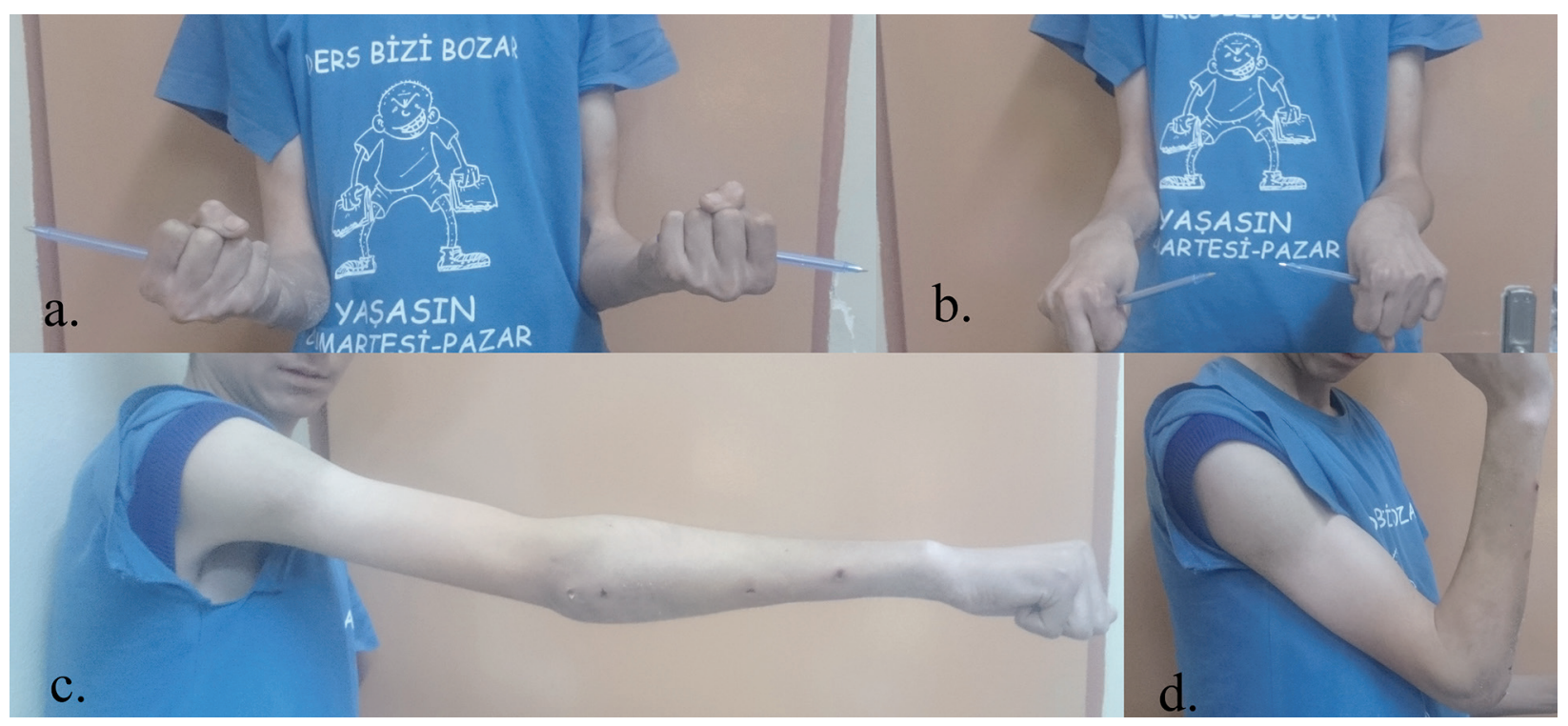

Figure 6. Early elbow range of motion: supination, pronation, extension, and flexion 


\section{DISCUSSION}

Since Almquist et al.[3] reported that CDRH can be bilateral, we took $\mathrm{x}$-rays of the contralateral elbow. Echtler and Burckhardt [4] followed four asymptomatic cases of CDRH because of the high risk of complications, including cubitus valgus, muscle weakness, and regrowth of the radial head, and observed no symptoms during follow-up. Deciding on a treatment method for $\mathrm{CDRH}$ remains challenging because there are few cases and none of the treatment modalities has predictable results. We wanted a method that would not harm the joint capsule in order to prevent contractures. We chose indirect reduction via reshaping the ulna and we used a CAHEF to assist with the bone alignment.

Bilen et al.[5] used ulnar lengthening and angulation osteotomy with llizarov external fixators to reduce three chronic radial head dislocations in 3-, 6-, and 8-year-old patients, with etiologies of ulnar hemimelia, brachial plexus injury, and CDRH. They used an llizarov frame that included the radius distally. After lengthening was finished, they modified the frame to enable angulation of the ulna to complete reduction. We used a computer-assisted hexapod fixator system with which we could easily change the position of the bone without the need for frame modification; our system did not include the radius, enabling us to start pronation and supination exercises soon after surgery without restriction.

Hasler et al. [6] reported the results of open radial head reduction and proximal ulnar dorsal angulation osteotomy with an external fixator in the treatment of twelve post-traumatic and three idiopathic cases of chronic radial head dislocation; their results included three repeat radial head dislocations and limited elbow extension. Rajasekaran and Venkatadass [7] reported the results of indirect radial head reduction using acute dorsal angulation and lengthening of the proximal ulna, but they did not give any information about the loss of elbow extension. Inevitably, extension of the elbow is limited by the dorsal angulation of the proximal ulna. Therefore, we chose proximal ulnar dorsal translation instead of angulation and successfully completed the indirect reduction without any joint contractures caused by scar tissue or heterotopic ossification, which occur with open intervention at the elbow.

Maruyama et al. [8] successfully treated an 11 -year-old chronic radial head dislocation caused by a missed Monteggia fracture dislocation with a snapping elbow using arthroscopic annular ligament release. They cited a Japanese report that postulated that the cause of the snapping in four cases of chronic radial head dislocation was the annular ligament. A reduced radial head and intact annular ligament have critical roles in elbow stability and range of motion. Therefore, we chose indirect reduction of the radial head without destroying the annular ligament.

Computer assisted external fixator system is a relatively new device. This system is a circular external fixators system which has no rigid hinge mechanism. Instead it has virtual hinges with the help of its configuration and software. When we consider only the device cost it seems relatively expensive than the classical systems. But correction of complex multiplanar deformities, in which the bone should be directed in more than one plane, as in our case with the classical llizarov frames it is necessary to treat patient with step by step fashion needing several stages of operations and changes in fixators configuration. Therefore the total cost of the treatment is nearly equal to the computer assisted system considering the several stages of operations, additional devices and hospitalization time. Also the new computer assisted system allows the surgeon to treat the patient with a single stage of operation. In case of need for modifications of the treatment it is possible to modify the system without any surgical intervention so that the complication risks are decreases.

In conclusion, although the literature suggests several treatment options, it is difficult to identify the best treatment method because of the limited number of reported cases. In this case, we successfully used CAHEF to obtain indirect radial head reduction and satisfactory results. This is a safe option for treating $\mathrm{CDRH}$.

\section{REFERENCES}

1. Karakoyun O, Erol MF, Küçükkaya M. Treatment of neglected elbow dislocations with the help of hinged external fixator: Report of two cases J Clin Exp Invest 2014;5:307-312.

2. Bengard MJ, Calfee RP, Steffen JA, et al. Intermediateterm to long-term outcome of surgically and nonsurgically treated congenital, isolated radial head dislocation. JHS 2012;37:2495-2501.

3. Almquist EE, Gordon LH, Blue Al. Congenital dislocation of the head of the radius. JBJS 1969;51:1118 1127.

4. Echtler B, Burckhardt A. Isolated congenital dislocation of the radial head. Good function in 4 untreated patients after 14-45 years. Acta Orthop 1997;68:598600 . 
5. Bilen FE, Kocaoglu M, Eralp L. Indirect reduction of the radial head using an external fixator to treat chronic radial head dislocations. AOTT 2010;44:14-19.

6. Hasler CC, Von Laer L, Hell AK. Open reduction, ulnar osteotomy and external fixation for chronic anterior dislocation of the head of the radius. JBJS $\mathrm{Br}$ 2005;87:88-94.
7. Rajasekaran S, Venkatadass K. "Sliding angulation osteotomy": preliminary report of a novel technique of treatment for chronic radial head dislocation following missed Monteggia injuries. Int Orthop 2014;38:25192524.

8. Maruyama M, Takahara M, Kikuchi N, et al. Snapping elbow with congenital radial head dislocation: case report. JHS 2010;35:981-985. 